\title{
UPAYA BADAN PELAYANAN PERIJINAN TERPADU DAN SATPOL PP TERHADAP PENERTIBAN PEMONDOKAN TIDAK MEMILIKI IJIN
}

\author{
Septa Kurnia Wahyudi \\ Program Magister Kenotariatan Fakultas Hukum Universitas Brawijaya \\ JI. MT. Haryono No 169; Malang; 65145; Indonesia; (0341) 553898 \\ pipposepta@gmail.com
}

\begin{abstract}
The issues raised based on the efforts made by the Integrated Licensing Service and Satpol PP Malang city in controlling the lodging business that has no permit in Malang and its obstacles. The approach method used is sociological juridical, using descriptive analysis. The results of the research can be seen that there are efforts that preventif, by patrolling and supervising tramtibum and enforcement of local regulations and decisions of the mayor and repressive efforts, among others by calling, examination, investigation, and Pengkasan news event examination (BAP) for filed in the Tipiring Session. Obstacles in the effort to curb this lodgement business there are 2 namely the internal and external barriers Satpol PP, external obstacles such as Lack of public understanding of the basic tasks Satpol PP, Ignorance of society against the applicable legislation. The bravery of local offenders violates officers. As for internal barriers such as the quality of existing employees is still lacking, the lack of educational background by personnel Satpol PP so as not been able to understand the duties and functions of the institution principal, and frequent personnel mutations so that less maximum coaching.
\end{abstract}

Keyword: Lodgings, Integrated Library Service Agency, Conversing Business Permits.

\begin{abstract}
Abstrak
Permasalahan yang diangkat berdasarkan upaya-upaya apa saja yang dilakukan oleh Badan Pelayanan Perijinan terpadu dan Satpol PP kota Malang dalam penertiban usaha pemondokan yang tidak memiliki ijin di Kota Malang serta hambatan-hambatannya. Metode pendekatan yang digunakan adalah yuridis sosiologis, dengan menggunakan deskriptif analisis. Adapun hasil penelitian dapat diketahui bahwa upaya tersebut ada macam yakni preventif, yaitu dengan melakukan patroli dan pengawasan tramtibum dan penegakan peraturan daerah serta keputusan walikota dan upaya represif, yakni antara lain dengan pemanggilan, pemeriksaan, penyidikan, dan Pemberkasan berita acara pemeriksaan (BAP) untuk diajukan di Sidang Tipiring. Hambatan dalam upaya penertiban usaha pemondokan ini ada 2 yakni hambatan dari internal dan eksternal Satpol PP, hambatan eksternal seperti Kurangnya pemahaman masyarakat akan tugas pokok Satpol PP, Ketidaktahuan masyarakat terhadap peraturan perundang-undangan yang berlaku. Keberanian pelanggar perda melanggar petugas. Sedang untuk hambatan internal antara lain kualitas pegawai yang ada masih kurang, latar belakang pendidikan yang kurang oleh personil Satpol PP sehingga belum mampu memahami tugas dan fungsi pokok lembaganya, dan seringnya mutasi personil sehingga pembinaan kurang maksimal.
\end{abstract}

Kata Kunci: Badan Pelayanan Perijinan Terpadu, Pemondokan, Ijin Usaha. 


\section{Pendahuluan}

Bahwa Kota Malang sebagai Kota Pendidikan, Industri dan Pariwisata akan berdampak pada banyaknya para pekerja/ karyawan/ karyawati, pelajar dan mahasiswa dari luar daerah yang berdatangan. Berdasar data yang ada, jumlah mahasiswa yang menempuh pendidikan tinggi di Kota Malang lebih dari 100 ribu orang mahasiswa yang tersebar di 47 perguruan tinggi (PT) swasta dan negeri. Dengan jumlah sebesar itu, tentunya secara otomatis para mahasiswa tersebut membutuhkan rumah pemondokan atau tempat tinggal. Sebagian besar mahasiswa tersebut berasal dari luar Kota Malang yang umumnya memilih kos di sekitar kampus masing-masing.

Di kota Malang terjadi di lingkungan sekitar universitas seperti kecamatan Dinoyo misalnya, hampir setiap warga di kawasan tersebut mempunyai rumah pemondokan. Belum lagi dengan daerah lain yang berada di sekitar kampus. Seperti, kawasan Universitas Brawijaya (UB) dan Universitas Negeri Malang (UNM) di Lowokwaru, Universitas Merdeka (UNMER) di Sukun. Bahwa demi pemenuhan kebutuhan pemondokan atau tempat tinggal yang tertib, layak, nyaman, aman bagi pekerja/ karyawan/ karyawati, pelajar dan mahasiswa dari luar daerah diperlukan patisipasi semua pihak untuk mewujudkannya. Dilatarbelakangi oleh hal tersebut maka Pemerintah Kota Malang membuat Peraturan Daerah tentang Penyelenggaraan Usaha Pemondokan yang diatur dalam Peraturan Daerah Kota Malang Nomor 6 tentang Penyelenggaraan Usaha Pemondokan.

Namun keberadaan Perda Nomor 6 tahun 2006 tentang Penyelenggaraan Usaha Pemondokan di Kota Malang hingga kini belum maksimal. Padahal, perda itu telah berlaku sejak tahun 2006 lalu. Indikasi kurang optimalnya perda itu adalah minimnya pemilik rumah kos yang mengurus izin. Data Badan Pelayanan Perizinan Terpadu (BP2T) menunjukkan bahwa pengurusan izin usaha pe- mondokan belum mencapai 100 permohonan. Padahal, dengan jumlah mahasiswa yang menempuh pendidikan tinggi di Kota Malang lebih dari 100 ribu orang mahasiswa tentunya secara tidak langsung membutuhkan pemondokan/ kostkostan yang tentunya juga dalam jumlah yang banyak pula.

Selain itu, berdasarkan data tahun 2008, pelanggaran usaha pemondokan hanya mencapai 16 penindakan. Sedang di tahun 2009, hingga bulan Juni tidak lebih dari 5 penindakan. Seperti kasus pelanggaran perda lainnya, pelanggaran perda pemondokan ini diproses melalui sidang tindak pidana ringan dengan denda mulai Rp 50 ribu sampai Rp 50 juta. Penutupan usaha pemondokan bisa dilakukan oleh Satuan Polisi Pamong Praja (Satpol PP) atau pun perangkat kelurahan setempat apabila pemondokan tersebut menerima pemondokan campuran, laki-laki dan perempuan berada dalam satu bangunan atau pemondokan tersebut menjadi tempat mesum. Pengecualian bagi suami istri, namun mereka juga harus menunjukkan surat nikah.

Pemerintah Daerah dalam hal ini instansi terkait adalah Badan Pelayanan Perijinan Terpadu wajib untuk melakukan pendataan bagi setiap rumah yang digunakan untuk pemondokan atau kos-kosan untuk keperluan pembinaan tertib kependudukan dan pemanfaatan. Dalam hal ini Badan Pelayanan Perijinan Terpadu berkoordinasi dengan Satpol PP yang bertindak sebagai penegakan terhadap pelanggaran Perda. Perda adalah suatu aturan hukum yang harus ditaati masyarakat untuk mengatur prilaku manusia dan kelompok manusia untuk terciptanya ketertiban dan kedamaian bersama. Oleh karena itu, peran hukum melalui perda ini penting untuk menjaga ketertiban pembangunan usaha pemondokan oleh rakyat untuk diatur dan dikelola dengan baik.

Penerapan suatu aturan dikatakan berjalan efektif jika masyarakat dapat menerima aturan kaidah tersebut sebagai hal yang berguna sehingga 


\section{Upaya Badan Pelayanan Perijinan Terpadu dan Satpol PP terhadap Penertiban Pemondokan Tidak Memiliki ljin}

Septa Kurnia Wahyudi

membuat masyarakat menjadi aman, tertib, dan damai. Lawrence Meir Friedman berpendapat mengenai efektifitas hukum, bahwa ada tiga elemen utama dalam system hukum (Legal System), (Friedman, 1975) yaitu (1) Subtansi Hukum (Legal Structure) yang artinya subtansi hukum merupakan isu case hukum itu sendiri.

Pengolahan dan uji kelayakan aturan hukum dilakukan oleh lembaga legislatif. Suatu kebijakan undang-undang harus sesuai dengan yang diharapkan dan dibutuhkan masyarakat. (2) Struktur Hukum (Legal Substance) yaitu Lembaga hukum di Indonesia terdiri dari dari lembaga-lembaga yang mempunyai andil dalam supremasi hukum dan mempunyai job discription sendiri-sendiri dalam mewujudkan penegakkan hukum. (3) Budaya Hukum (Legal Culture) adalah Budaya Hukum hal yang tumbuh dan berkembang serta menjadi kebiasaan di masyarakat.

Soerjono Soekanto mengetengahkan hal-hal yang menyebabkan suatu aturan menjadi efektif (Salman \& Susanto, 2012) yaitu; a. Faktor produk hukum; b. Faktor Pelaku hukum; c. Faktor sarana dan fasilitas yang mendukung penegakan hukum; d. Faktor kesadaran masyarakat; e. Faktor budaya hukum. Faktor-faktor tersebut diatas menjadi suatu perhatian yang lebih, terlebih dalam pembuatan suatu peraturan ditingkat daerah khususnya maupun ditingkat pusat. Sehingga dapat memberikan kemanfaatan dan daya guna akan peraturan tersebut serta ditaati sepenuhnya oleh masyarakat karena memiliki kebaikan bagi kehidupanya.

Berdasarkan Teori Kewenangan Soerjono Soekamto menguraikan perbedaan antara "kekuasaan" dan "wewenang" hal yang dapat menguasai dan mempengaruhi orang lain disebut "kekuasaan", sedangkan wewenang adalah kekuasaan yang ada pada seseorang atau sekelompok orang, yang mendapat pengakuan dari dan dukungan dari sekelompok masyarakat (Soekanto, 2003).

Hal ini sejalan dengan upaya untuk mencapai tujuan hukum yaitu menurut Gustav Radbruch mengajarkan tentang tiga konsep atau ide unsur dasar hukum (Sidharta, 2007) yaitu: a. Kepastian Hukum b. Keadilan Hukum c. Manfaat Hukum. Berdasarkan teori tujuan hukum menurut Gustav Radbruch harus ada skala prioritas yang harus dijalankan, dimana prioritas pertama adalah keadilan hukum, kemudian kemanfaatan hukum, dan yang terakhir adalah kepastian hukum (Sidharta, 2007).

Demi tercapainya tujuan hukum yang menuntut kedamaian, ketentraman, kesejahterahan dan ketertiban dalam masyarakat, asas prioritas dalam tujuan hukum yang dikemukakan oleh Gustav Radbruch dapat dijadikan sebagai dasar dan pedoman serta panduan, apalagi dengan kondisi masyarakat Indonesia yang sedemikian plural dan kompleks dari berbagai latar belakang.

Terlebih bahwa Indonesia sebagai negara hukum mempunyai karakteristik tersendiri jika dibanding dengan konsep negara hukum rechtsstaat maupun konsep negara hukum the rule of law. Meskipun sama-sama lahir untuk menentang adanya kesewenang-wenangan atau absolutisme tetapi konsep negara hukum di Indonesia didasarkan pada ideologi Pancasila yang berbeda dengan liberalisme, kapitalisme, maupun sosialis. Berdasarkan hal ini, negara hukum di Indonesia disebut dengan negara hukum Pancasila (Sunarjo, 2014).

Berdasarkan latar belakang yang telah diuraikan diatas, rnaka penelitian ini mengkaji upaya badan pelayanan perijinan terpadu dan satpol pp terhadap penertiban pemondokan yang tidak memiliki ijin dan selanjutnya akan mengkaji dan menganalisis secara lebih mendalam tentang beberapa permasalahan, yaitu upaya-upaya apa saja yang dilakukan oleh Badan Pelayanan Perizinan Terpadu dan Satuan Polisi Pramong Praja dan dalam rangka penertiban terhadap pemondokan yang tidak memiliki Ijin. Kendala-kendala apa saja yang dihadapi oleh Badan Pelayanan Perizinan Terpadu dan Satuan Polisi Pamong Praja dalam melaksanakan Penertiban terhadap pemondokan yang tidak memiliki Ijin pemondokan. 
Penelitian difokuskan untuk menemukan solusi dan juga meningkatkan pemahaman serta efektifitas hukum khususnya penegakan Perda No. 6 tahun 2006 tentang Penyelenggaraan Usaha Pemondokan di kota Malang. Sehingga diharapkan dengan penertipan usaha pemondokan di kota Malang juga diharapkan dapat memberikan kepastian hukum bagi pengusahanya sendiri dan juga kemanfaatan yang lebih bagi pemerintah daerah khususnya terhadap pemasukan atau pendapatan daerah.

\section{Metode Penelitian}

Kajian dalam tulisan ini lebih mengarah kepada pendekatan hukum empiris dikarenakan mencoba menggali hukum yang dikonsepkan sebagai suatu gejala empiris yang dapat diamati di dalam kehidupan, dalam hal ini bagaimanakah peran negara dalam mengatur secara normatif upaya badan pelayanan perijinan terpadu dan satpol pp terhadap penertiban pemondokan yang tidak memiliki ijin karena itu juga perlunya mengkaji peraturan-peraturan (Indrayanti \& Entah, 2015). Jenis Penelitian Hukum Empiris ini yaitu penggabungan antara pendekatan hukum normatif dengan adanya penambahan dari berbagai unsurunsur empiris (Indrayanti dan Entah, 2015). Dengan Lokasi Penelitian ini dilaksanakan di kantor badan Pelayanan Perijinan Terpadu dan Satpol PP yang ada di Kabupaten Malang.

Penelitian ini menggunakan metode pendekatan yuridis sosiologis. Menggunakan metode penelitian yuridis sosiologis adalah untuk mengkaji permasalahan dari segi hukum normatif yaitu Perda kota Malang Nomor 6 tahun 2006 didasarkan pada kenyataan-kenyataan yang ada dilapangan dengan populasi dalam penelitian ini meliputi semua bagian dalam Kantor Badan Pelayanan Perijinan Terpadu dan Satpol PP Kota Malang. Serta Sampel meliputi, Kepala Kantor Badan Pelayanan Perijinan Terpadu Kota malang, Kepala Satpol PP KotaMalang serta jenis dan sumber data diantaranya bersumber dari data primer meliputi; Wawancara, Kuisioner, data sekunder terdiri dari data sebagai berikut; Data Hukum Primer, Data Hukum Sekunder, Data Hukum Tersier. Teknik analisis yang digunakan secara yuridis kualitatif, artinya dari data yang diperoleh selanjutnya dianalisis dan disusun secara sistimatis, sehingga mencapai suatu kejelasan sesuai dengan permasalahan, sehingga diperoleh suatu kesimpulan yang tepat dan benar atas persoalan yang di teliti.

\section{Hasil Penelitian}

A. Upaya-Upaya yang Dilakukan oleh Badan Pelayanan Perijinan Terpadu dan Satpol PP Dalam Penyelesaian Penertiban Ijin Usaha Pemondokan

Hasil temuan di lapangan, dalam hal terjadinya pelanggaran terhadap Ijin Usaha Pemondokan di Kota Malang, Badan Pelayanan Perijinan Terpadu Kota Malang tidak melakukan penegakan hukum sama sekali, Badan Pelayanan Perijinan Terpadu dalam hal ini hanya memberikan pelayanan kepada masyarakat terhadap permohonan ijin yang tercantum pada Surat Peraturan Walikota Malang Nomor 8 Tahun 2009 yang terdiri dari 12 jenis ijin.

Penindakan atau penegakan hukum terhadap pemondokan yang tidak memiliki Ijin Usaha Pemondokan dalam hal ini dilakukan oleh Satpol PP Kota Malang yang berperan sebagai penindak pelanggaran atas Perda No. 6 Tahun 2006 tentang Penyelenggaraan Usaha Pemondokan. Penertiban yang dilakukan Satpol PP biasanya berkoordinasi terlebih dahulu dengan masyarakat setempat dalam hal ini adalah Ketua RT/ RW. Satpol PP berkoordinasi untuk mendapat keterangan tentang siapa-siapa saja yang memiliki usaha pemondokan/ kost-kosan di lingkungan itu.

Setelah adanya koordinasi dengan masyarakat, Satpol PP melakukan tindakan-tindakan sebagaimana tersebut, mekanisme Pelaksanaan Trantibum dan Penegakan Perda Kota Malang 
diantaranya tindakan Preventif dengan cara Panggilan I dan II, tindakan Represif dengan cara Pemberkasan dan Sidang.

Upaya preventif adalah upaya pencegahan terhadap terjadinya pelanggaran yang dilakukan dengan cara malakukan patroli dan pengawasan tramtibum atas penegakan peraturan daerah serta keputusan walikota. Bagan berikut merupakan langkah-langkah dalam Pelaksanaan Tramtibum dan Penegakan Perda Kota Malang yang bersifat preventif.

\section{a. Mekanisme Preventif}

1. Seksi Operasional dan Pengawasan dan/ atau Seksi Ketentraman Ketertiban mendapatkan informasi tentang adanya indikasi pelanggaran baik laporan secara langsung, yaitu melalui pengawasan rutin atau patroli dilapangan, maupun secara tidak langsung yaitu laporan dari dinas terkait atau laporan dari masyarakat;

2. Berdasarkan hasil temuan atas indikasi pelanggaran yang terjadi, kedua seksi tersebut membuat laporan yang ditujukan kepada Seksi Penyidikan dan Penindakan yang kemudian akan dilanjutkan pada proses selanjutnya;

3. Atas laporan tersebut seksi Penyidikan dan Penindakan melanjutkan proses dengan melaksanakan:

i. Pemanggilan,yaitu pemanggilan yang ditujukan pada subyek yang berindikasi melakukan pelanggaran;

ii. Klarifikasi, yaitu proses tanya jawab antara Seksi Penyidikan dan Penindakan dari Satpol PP terhadap subyek yang terkait indikasi pelanggaran yang terjadi;

iii. Penyuluhan, yaitu proses pemberian solusi kepada pelanggar yang terindikasi melakukan pelanggaran, agar pada proses selanjutnya tindakan yang diambil tidak lagi melanggar ketentuan yang berlaku; iv. Pembinaan, yaitu proses pengawasan ataupun penyuluhan yang diusahakan agar tidak tcrjadi pelanggaran di kemudian hari.

Berdasarkan mekanisme di atas dalam perkembangannya diharapkan menekan pelanggaran masyarakat. Namun pada beberapa kasus pidana, khususnya kasus pidana yang besar dalam artian menyita perhatian publik cukup banyak, upaya preventif ini masih diragukan efektivitasnya (Putra, 2016). Hal tersebut juga terjadi dalam tindakan Satpol PP tidak menunjukkan upaya atau fungsi preventifnya sebagai bagian dari kebijakan penanggulangan perbuatan pembangunan usaha pemondokan tanpa ijin. Namun justru lewat proses penindakan Satpol PP sebenarnya merupakan penegakan hukum preventif dimana memberikan kesadaran hukum bagi masyarakat lainmya yang hendak mendirikan bangunan. Fenomena inilah yang menarik untuk dikaji, apakah posisi Satpol PP saat ini sudah tepat dalam konteks kebijakan penanggulangan.

\section{b. Mekanisme Represif}

Upaya represif adalah upaya pcnegakan hukum atas terjadinya pelanggaran yang dilakukan dengan cara menindak dan memberikan sanksi kepada subyek pelanggar peraturan daerah serta keputusan walikota. Tindakan yang diberikan 1. Pemanggilan, 2. Pemeriksaan, 3. Penyidikan, 4. Pemberkasan berita acara pemeriksaan (BAP) untuh diajukan di Sidang Tipiring dengan mekanismenya sebagai berikut:

1. Seksi Operasi Pengawasan (SIE OPWAS) dan Seksi Ketentraman dan Ketertiban (SIE TRANTIB) mendapati adanya pelanggaran yang terjadi yang selanjutnya melimpahkan kepada Seksi Penyidikan dan Penuntutan;

2. Seksi Penyidikan dan Penindakan dalam hal ini diwakili oleh Penyidik Pegawai Negeri Sipil (PPNS) Melakukan koordinasi 
dengan Sub Bagian Tata Usaha untuk membuat Berita Acara Pemeriksaan (BAP) yang kemudian dilimpahkan kcpada Bagian Hukum Satpol PP dan Polresta Malang (selaku KORWAS);

3. Bagian Hukum Satpol PP dan Polresta Malang (selaku KORWAS) memeriksa dan melengkapi semua berkas yang diperlukan agar BAP yang kemudian dilimpahkan ke Kejaksaan Negeri untuk segera diproses di pengadilan pengadilan dapat dilaksanakan di Pengadilan Negeri maupun di Kantor Satpol PP Kota Malang.

Terkait dengan penelitian ini, serta sesuai dengan Mekanisme Pelaksanaan Tramtibum dan Penegakan Perda dan Keputusan Walikota Malang dalam hal terjadinya pelanggaran Ijin Usaha Pemondokan, Satpol PP melakukan tindakan Represif seperti yang telah dijelaskan sebelumnya. Setelah dilakukan penindakan terhadap subyek hukum pelanggar maka subyek hukum pelanggar tersebut dikenakan sanksi yang dapat berupa:

\section{Sanksi administrasi}

Setiap pemilik yang tidak memenuhi kewajiban pemenuhan fungsi, dan persyaratan atau penyelenggaraan usaha pemondokan sebagaimana dimaksud dalam Peraturan Daerah dikenai sanksi administrasi berupa:
a. Peringatan tertulis;
b. Pencabutan ijin usaha pemondokan;
c. Penutupan usaha pemondokan.

Berdasarkan jenis-jenis sanksi diatas merupakan jenis sanksi yang diajukan penuntut umum (jaksa) untuk memberikan sanksi bagi pelanggar perbuatan usaha pemondokan tanpa ijin. Penuntut umum selayaknya mempertimbangkan perlindungan hukum bagi konsumen atau masyarakat sebagai korban, serta aspek penjeraan bagi pelaku dan pencegahan bagi calon pelaku lainnya (Mulyono, 2017). Pertimbangan perlindungan hukum bagi konsumen perlu mendapatkan perhatian serius dari pihak penuntut umum dalam melakukan penuntutan, dikarenakan usaha pemondokan yang tidak layak merupakan kerugian bagi konsumen. Bagi masyarakat, pemondokan tidak sesuai dengan penyelenggaraan usaha pemondokan akan berdampak pada keadaan sosial masyarakat.

Sanksi-sanksi di atas yang diharapkan memberikan efek jera, sehingga tidak berlanjut kepada tindakan represif. Sanksi administratif adalah sanksi dengan mengutamakan pendekatan persuasif yang menekankan kesadaran akan kewajiban pihak pemilik usaha pemondokan untuk mengurus ijin pemondokanya. Sehingga biasanya dalam pemberian sanksi ini lebih kepada pemberian toleransi dengan batas waktu tertentu sehingga apabila batas waktu tertentu tidak segera di lakukan maka baru akan dilakukan tindakan represif. Hal ini dilakukan semata-mata untuk memberikan dukungan moral bagi para pengusaha pemondokan dan agar supaya masyarakat lain yang belum memiliki usaha pemondokan untuk tidak trauma atau tidak merasa dipersulit dalam mendirikan usaha pemondokan. Terlibih di kota malang sebagai kota pendidikan yang amat potensial dalam usaha pemondokan.

2. Sanksi Pidana

Sanksi pidana sebagai tindakan ultimum remidium artinya sebagai upaya terakhir untuk memberikan efek jera kepada masyarakat yang wajib mengurus ijin usaha pemondokan namun dengan sengaja tidak mengurusnya. Hal ini sebagaimana diatur dalam Perda No. 6 tahun 2006 yang dinyatakan bahwa Setiap pemilik yang terbukti melanggar ketentuan sebagaimana yang diatur dalam pasal 8, pasal 9, pasal 10, pasal 11, dan pasal 12, diancam dengan pidana kurungan paling lama 3 (tiga) bulan atau denda paling banyak Rp 10.000.000,00 (sepuluh juta rupiah) dimana tindak pidana yang dimaksud disini adalah pelanggaran. 
Latar belakang perbuatan pelanggaran itu marak terjadi berdasarkan temuan lapangan terdapat beberapa faktor antara lain:

a. Belum adanya sosialisasi yang jelas dan merata dari pihak pemerintah sehingga pemilik usaha pemondokan belum mengetahui adanya Perda Nomor 6 tahun 2006 tentang Penyelenggaraan Usah Pemondokan;

b. Pemilik usaha beranggapan dengan dengan adanya ijin usaha akan menambah beban biaya baru buat pengurusannya;

c. Belum adanya sidak dari Satpol PP. Ini adalah fakta yang perlu dipertimbangkan, sehingga alasan ketidak tahuan akan peraturan yang mewajibkan masyarakat untuk menaatinya tidak menjadi pembenar akan tindakan yang dilakukanya. Untuk menjadi suatu kewajiban bagi pemerintah daerah kota malang untuk meningkatkan sosialisasi dan mencari cara praktis dalam memberikan pemahaman akan peraturan-peraturan daerah yang telah dibuatnya. Terlebih peraturan-peraturan daerah yang mengikat masyarakat secara umum.

\section{B. Hambatan Dalam Penegakan Hukum Terhadap Penertiban Pemondokan yang tidak Memiliki Ijin}

Upaya yang dilakukan oleh badan pelayanan perijinan terpadu dan satpol pp dalam penyelesaian penertiban ijin usaha pemondokan tentunya tidaklah mudah. Hal ini tidak terlepas dari bagaimana respon dari masyarakat khususnya yang memiliki pemondokan yang wajib memiliki ijin. Untuk itu diperlukan pengetahuan dan informasi yang baik dalam mengali dan menemukan serta menganalisa hambatan-hambatan di dalam upaya yang dilakukan untuk menertibkan pemondokan yang wajib memiliki ijin.

Hambatan yang dihadapi oleh Satpol PP Kota Malang dalam melakukan penegakan hukum terhadap penertiban pemondokan yang tidak memiliki ijin maka muncul dua macam hambatan yaitu, hambatan yang bersifat eksternal, (hambatan yang berasal dari luar lembaga) yang termasuk dalam hambatan ini adalah:

a. Kurang perhatian dan pemahaman masyarakat pada tugas pokok dan fungsi Satpol PP bukan hanya dalam pclaksanaan ketertiban umum dan ketentraman masyarakat melainkan juga pengawasan dan penegakan peraturan daerah serta keputusan walikota Malang;

b. Masyarakat kurang sadar akan Peraturan Daerah yang berlaku;

c. Keberanian pelanggar Peraturan Daerah terutama PKL untuk melawan petugas.

Sedangkan hambatan yang bcrasal dari internal (Hambatan yang berasal dari dalam lembaga) pada Satpol PP Kota Malang pada umumnya berkisar pada kualitas dan kinerja personel pada Satpol PP Kota Malang meliputi;

a. Kualitas sumber daya manusia yang ada belum seluruhnya merniliki pengetahuan dan pelatihan dibidang penegakan dalam penindakan pelanggaran Perda;

b. Lalar belakang pendidikan formal sebagian besar personil yang masih terbilang rendah sehingga belum cukup mampu memahami tugas pokok dan fungsi lembaganya;

c. Seringnya terjadi mutasi personil, sehingga pembinaan tentang pengctahuan dan pelatihan dibidang penegakan dalam penindakan pelanggaran Perda kurang maksimal.

Hambatan-hambatan tersebut diataslah yang kemudian menjadi penyebab persoalan ketidak maksimalnya upaya penertiban pemondokan untuk itu diperlukan terobosan-terobosan penyelesaian sehinga bisa menjadi upaya untuk mencairkan atau mengatasi persoalan yang dihadapi oleh penegakan peraturan tentang kewajiban memiliki ijin bagi pemondokan khususnya pemondokan yang wajib memiliki ijin. 


\section{Upaya Guna Mengatasi Hambatan Dalam Penegakan Hukum Terhadap Penertiban Pemondokan yang Tidak Memiliki Ijin}

Terkait dengan adanya beberapa hambatan seperti yang telah disebutkan dalam latar belakang maka Satpol PP Kota Malang mengambil langkah inisiatif rrntuk mengatasi hambatan-kendala yang ada. Guna mengatasi hambatan yang bersifat eksternal Satpol PP Kota Malang melakukan:

a. Pendekatan kepada Tokoh masyarakat yang diharapkan dapat berpengaruh terhadap kesadaran masyarakat untuk mematuhi semua norma, peraturan dan hukum yang berlaku;

b. Melakukan interaksi dan sosialisasi baik secara langsung, maupun tidak langsung kepada masyarakat perihal berlakunya Peraturan Daerah dan Keputusan Walikota Malang;

c. Penyampaian informasi melalui media massa dan elektronik.

Selanjutnya, guna mengatasi hambatan yang bersifat internal,satpol PP Kota Malang melakukan:

a. Memberikan pelatihan-pelatihan baik dilakukan oleh intern atau (in house training) Satpol PP kota Malang maupun melalui lembaga-lembaga lain yang dapat meningkatkan kinerja personil Satpol PP Kota Malang atau (out house training);

b. Memberikan evaluasi-evaluasi secala berkala terhadap kinerja para Personil Satpol PP Kota Malang, serta memberikan solusi tcrhadap evaluasi-evaluasi tersebut;

c. Mengupayakan untuk menambah dan meningkatkan sarana dan prasarana penunjang kinerja personil pada Satpol PP Kota Malang.

Upaya-upaya diatas adalah cara untuk memberikan solusi atas persoalan yang bersifat internal maupun eksternal sehingga diharapkan dapat meminimalisir persoalan dan memaksimalkan kesadaran masyarakat untuk mengurus ijin pemondokan bagi para pemilik usaha pemondokan. Hal ini supaya peraturan yang dibuat dapat memberikan rasa aman, tertib dan kepastian hukum bagi masyarakat khususnya pemilik usaha pemondokan.

\section{Kesimpulan}

Berdasarkan pada uraian-uraian yang telah di sampaikan sebelumnya maka dapat diambil kesimpulan bahwa upaya penyelesaian penertiban terhadap Ijin Usaha Pemondokan di Kota Malang hanya dilakukan oleh Satpol PP Kota Malang, sedangkan Badan Pelayanan Perijinan Terpadu hanya berfungsi untuk melayani pemrosesan Ijin Usaha Pemondokan tersebut. Tindakan-tindakan yang dilakukan oleh Satpol PP dalam hal terjadinya penertiban terhadap Ijin Usaha Pemondokan dapat dikategorikan menjadi Upaya Preventif dan Upaya Represif. Hambatan yang dihadapi oleh Satpol PP Kota Malang dalam melakukan penegakan hukum terhadap pemondokan yang tidak memiliki Ijin Usaha Pemondokan, dapat digolongkan menjadi dua macam harnbatan yaitu yang bcrsifat eksternal dan internal.

\section{Saran}

Pihak Pemerintah Daerah harus lebih mensosialisasikan Peraturan Daerah Nomor 6 Tahun 2006 tentang Penyelenggaraan Usaha Pemondokan khususnya terkait dengan Ijin Usaha Pemondokan. Pemerintah daerah khususnya aparat yang berwenang seperti petugas Satpol PP lebih tegas dan sering melakukan sidak ke kawasan yang banyak terdapat usaha pemondokan.

\section{DAFTAR PUSTAKA}

Aswar, Saifuddin. 2003. Metode penelitian. Pustaka pelajar. Yogjakarta.

Effendi, Lutfi. 2004. Pokok-Pokok Hukum Administrasi. Bayumedia Publishing. Malang. 


\section{Upaya Badan Pelayanan Perijinan Terpadu dan Satpol PP terhadap Penertiban Pemondokan Tidak Memiliki ljin}

Septa Kurnia Wahyudi

Hadjon, Philipus M., 1993, Pengantar Hukum Perijinan, Yuridika, Surabaya.

HR, Ridwan. 2006. Hukum Administrasi Negara. Raja Grafindo Persada. Jakarta.

Indrayanti, K., \& Entah, A. 2017. Peran Negara Dalam Memberikan Perlindungan Hukum Bagi Calon Pasangan Kawin Beda Agama (KBA) Di Indonesia. Jurnal Cakrawala Hukum, 6(1), 56-66. doi:10.26905/ idjch.v6i1.685.

Mulyono, G. 2017. Perlindungan Hukum Bagi Konsumen Pada Kasus Keamanan Pangan oleh Kejaksaan. Jurnal Cakrawala Hukum, 8(1), 44-54. doi:10.26905/ idjch.v8i1.1729

Peraturan Daerah Kota Malang Nomor 6 Tahun 2006 tentang Penyelenggaraan Usaha Pemondokan.

Siswosoediro, Henry S. 2007. Mengurus Surat-Surat Perizinan. Visimedia, Jakarta.

Soehiono. 1994. Asas-Asas Hukum Tata Pemerintahan. Liberty. Yogyakarta.
Sunarjo, S. 2017. Peradilan Sebagai Pilar Negara Hukum Dalam Perspektif Pancasila. Jurnal Cakrawala Hukum, 19(1), 71-81. doi:10.26905/idjch.v19i1.1132.

Sunggono, Bambang. 1998. Metode penelitian Hukum. Raja Grafindo persada. Jakarta.

Suryo, Anak. 2007. Tata Cara Mengurus Ijin Usaha. Pustaka Yudisia. Yogyakarta.

Syafrudin, Ateng. 1997. Perizinan untuk Kegiatan Tertentu Edisi 23. Majalah Hukum Media Komunikasi FH Unpas. Bandung.

Zein. Sutan, Muhammad dan Badudu. 2001. Kamus Umum Bahasa Indonesia Edisi keempat. Pustaka Sinar Harapan. Jakarta.

\section{How to cite:}

Wahyudi, Septa Kurnia. 2017. Upaya Badan Pelayanan Perijinan Terpadu dan Satpol PP Terhadap Penertiban Pemondokan Tidak Memiliki Ijin. Jurnal Cakrawalah Hukum, 8(2). 